\title{
Discussion on the optimal portfolio of insurance companies
}

\author{
Sixing Zhang \\ School of economics and management, North China Electric Power University, 689 Huadian Road, \\ North District, Baoding China \\ 2371736732@qq.com
}

Keywords: optimal portfolio; linear programming; covariance.

\begin{abstract}
With the rapid development of China's insurance industry, the insurance funds are becoming larger and larger. However, behind the rapid development of the insurance industry, some problems have become increasingly prominent such as lower revenue and insufficient repayment. The purpose of this paper is to find an optimal portfolio strategy for China's insurance companies to make best use of existing funds and provide guidance, combining the current situation in China. First, through international comparison, we can find our current problems: narrow investment channel and low profitability. Second, we conduct a mathematical model to find the optimal strategy which is suitable for most companies. Third, we take Ping An Group Insurance Company for example and compute the proportion of each form of investment. Conclusions and suggestions are put forward finally.
\end{abstract}

\section{Introduction}

Since the reform and opening up, China's insurance industry has maintained a sustained and stable development trend. The underwriting business and investment business as two pillars industry play an irreplaceable role in development of insurance industry. With the development of the financial liberalization and innovation, the insurance company has developed into a vital important institutional investor in capital market. Improving investment returns becomes an important mean for them to improve competitive power. However, because of a last start, slow development and backward technology, the development of China's insurance industry has seriously hampered. Compared to Western countries, it's still at an early stage of development. Although the investment business has begun to take shape and have some investment experience, there are still many problems to be addressed.

Recently, the China Insurance Regulatory Commission (CIRC) has introduced 13 regulations, particularly including the use of insurance funds. The implementation of the new regulations broadens the investment and relaxes the restrictions. Our investment of insurance funds is facing an unprecedented new opportunities and challenges. So how to adjust their investment strategies for insurance companies is the current problem that must be solved. The purpose of this paper is to explore an optimal portfolio strategy model for China's insurance companies and make investment recommendations, combining actual situation and the related policies.

\section{The basic concept of insurance investments}

\subsection{Insurance investment.}

Investment Insurance (also known as insurance funds investment) refers to an economic activity to achieve the purpose of increasing the value of the funds, which temporarily uses idle funds for investment or financing of insurance in order to obtain benefits in the process of organizing economic compensation, increasing the value of the Fund.

\subsection{Capital source and main investment channels.}

Insurance funds mainly include accumulation fund, capital fund, reserves fund, undistributed profits and other funds, raised through a variety of channels. Insurance funds must follow the 
principles of integrity and security, and its management has the feature of intensive, professional, standardized and marketization. Generally speaking, China's insurance investment channels are: bank deposits, bonds, securities investment, stocks, loans, foreign investment, and real estate.

\section{Current situation and International comparison}

\subsection{Current situation}

Narrow investment channels. The developed countries whose insurance originated earlier, their insurance funds cover almost all investment channels of investment and financing for the domestic and foreign markets. In this way, the investment channels of our country appear to narrow.

Low profitability. Under the pressure of competition, insurance companies often pursue high yield, ignoring the control of the risk. Meanwhile, lacking investment channels results in lower yields. In fact, the vast majority of funds are deposited in banks or used to buy government bonds, up to $80 \%$.

Portfolio Strategy management needs to be improved. Most insurance companies have not yet established a scientific and standardized system to develop and select the portfolio strategy. Lack of investment talent and investment experience and immaturity of investment philosophy have influenced the development of insurance company investments.

\subsection{International comparison}

Table1. Capital distributing of insurance of America (\%) [1]

\begin{tabular}{cccccccc}
\hline & Bond & Preferred Stock & Common Stock & Loan & Real Estate & Cash & Others \\
\hline 2008 & $71.22 \%$ & $2.12 \%$ & $1.63 \%$ & $14.82 \%$ & $0.66 \%$ & $4.85 \%$ & $4.7 \%$ \\
2009 & $71.22 \%$ & $2.12 \%$ & $1.63 \%$ & $14.82 \%$ & $0.66 \%$ & $4.85 \%$ & $4.7 \%$ \\
2010 & $75.93 \%$ & $0.28 \%$ & $2.12 \%$ & $13.47 \%$ & $0.62 \%$ & $2.98 \%$ & $4.6 \%$ \\
\hline
\end{tabular}

Table2. Capital distributing of insurance of UK (\%) [2]

\begin{tabular}{ccccccc}
\hline & Public securities & Stock & Overseas securities & Trust fund & Asset & Cash \\
\hline 2008 & $18.46 \%$ & $38.36 \%$ & $14.81 \%$ & $11.58 \%$ & $6.92 \%$ & $9.87 \%$ \\
2009 & $17.7 \%$ & $40.3 \%$ & $14.20 \%$ & $13.59 \%$ & $5.97 \%$ & $8.24 \%$ \\
2010 & $18.04 \%$ & $39.58 \%$ & $14.24 \%$ & $15.31 \%$ & $5.97 \%$ & $6.86 \%$ \\
\hline
\end{tabular}

After comparison and analysis, we can find the diversified investment tools in these countries, which not only involve ordinary bonds, stocks, deposits, but also involve many innovative investment tools, such as real estate, overseas investment. Not only securities and other virtual economy competitive, but also real economy do they invest in the domestic and global market. Modern portfolio theory proposes that the diversification of investment can be effectively dispersed non-systematic risk. Therefore, the diversification of investment is in favor of insurance companies to pursue higher returns under the premise of the safety.

\section{The determination of the optimal portfolio insurance}

As an old saying goes, do not put all your eggs in one basket. Rational people know how to take advantage of the investment portfolio to diversify risk. Markowitz put forward the portfolio theory in 1952 and first proposed the Variance which represented the risk. So the benefits and risks can be measured directly.

\subsection{Basic assumption}

Investment effect summarizes by the appropriate rate of return properly. Investors can obtain various probability distribution formed by yield change.

Indexes that investors use to estimate the risk are the variance of rate of return.

Assets and liabilities have complete mobility. 


\subsection{Independent variables}

Underwriting profitability because the insurance company's incomes are mainly from investment and underwriting, this paper defines that underwriting profit equals to the total profits deducting investment profits.

Table3. 2007-2011 Underwriting profitability of Ping An Group Insurance Company (Million) [3]

\begin{tabular}{cccccccc}
\hline & 2009 & 2010 & 2011 & 2012 & 2013 & 2014 & Average \\
\hline Underwriting profit & -4398 & -5732 & -4812 & -5988 & -7204 & -5947 & $/$ \\
\hline $\begin{array}{c}\text { Insurance business income } \\
\text { Change in unexpired liability }\end{array}$ & 129383 & 112213 & 159384 & 207802 & 233940 & 269051 & $/$ \\
$\begin{array}{c}\text { reserve } \\
\begin{array}{c}\text { Change in long-term liability } \\
\text { Chang }\end{array}\end{array}$ & 22 & 17 & 19 & 309 & 11 & 670 & $/$
\end{tabular}
reserve

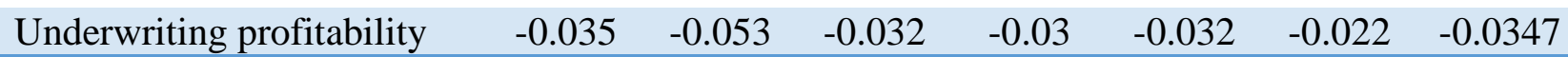

The rate of return in this paper, securities investment funds, stocks, bonds and corporate bonds are identified as risk assets. Its average annual investment rates of return are as follows:

Table 4. The average market investment return rate of the risk asset [4]

\begin{tabular}{cccccccc}
\hline & 2009 & 2010 & 2011 & 2012 & 2013 & 2014 & Average \\
\hline Government bonds (\%) & 3.95 & 3.97 & 3.59 & 3.52 & 2.69 & 4.21 & 3.655 \\
Corporate bonds (\%) & 4.21 & 3.89 & 3.81 & 3.02 & 2.58 & 5.56 & 3.845 \\
Stock (\%) & 95.6 & 16.8 & -9.09 & 22.41 & 10.56 & 47.74 & 30.67 \\
Funds (\%) & 62.65 & 2.64 & 3.6 & -7.41 & -13.90 & 48.42 & 16 \\
\hline
\end{tabular}

Restrictions on assets investment According to "Tentative measures of insurance funds to invest" issued by CIRC, specific requirements are as follows:

Table 5. The ratio of Assets can be invested and allocation (\%) [5-6]

\begin{tabular}{ccccccc}
\hline $\begin{array}{c}\text { Investment } \\
\text { assets }\end{array}$ & $\begin{array}{c}\text { Bank } \\
\text { deposits }\end{array}$ & $\begin{array}{c}\text { Government } \\
\text { bonds }\end{array}$ & $\begin{array}{c}\text { Corporate } \\
\text { bonds }\end{array}$ & Funds & Stock & $\begin{array}{c}\text { Real } \\
\text { Estate }\end{array}$ \\
\hline Limit & $\begin{array}{c}\text { No upper } \\
\text { limit }\end{array}$ & No upper limit & $50 \%$ & $25 \%$ & $30 \%$ & $30 \%$ \\
\hline
\end{tabular}

The determination of risk-free investment yields Bank deposits is generally regarded as risk-free assets with a small risk characteristic. China's insurance company's bank deposits mainly include time deposits and large agreement deposits, their respective APRs are as follows:

Table 6 The risk-free interest rate $(\%)$ [7]

\begin{tabular}{cccccccc}
\hline & 2009 & 2010 & 2011 & 2012 & 2013 & 2014 & Average \\
\hline Time deposits \% & 2.25 & 2.75 & 3 & 3.5 & 3.25 & 3 & 2.96 \\
Agreement deposit \% & 1.17 & 1.18 & 1.21 & 1.31 & 1.15 & 1.16 & 1.20 \\
Average \% & 1.71 & 1.965 & 2.105 & 2.405 & 2.2 & 2.08 & 2.08 \\
\hline
\end{tabular}

Average utilization rate of capital The average utilization rate of capital of insurance company is the symbol to measure the level of funds, the usage of funds of Ping An Group Insurance Company each year are listed below:

Table7 The average capital usable ratio of insurance companies (Million)[3,8]

\begin{tabular}{cccccccc}
\hline & 2009 & 2010 & 2011 & 2012 & 2013 & 2014 & Average \\
\hline Investment Assets & 639275 & 813185 & 954256 & 2002798 & 2408056 & 2943717 & $/$ \\
Total capital & 707640 & 935712 & 1171627 & 2285424 & 2844266 & 3360312 & $/$ \\
Investment proportion\% & $90.33 \%$ & $86.90 \%$ & $81.45 \%$ & $87.63 \%$ & $84.66 \%$ & $87.60 \%$ & $86.43 \%$ \\
\hline
\end{tabular}




\subsection{The portfolio model}

Insurance funds must be decentralized, considering not only risks and earnings, but also underwriting risks. Assume to invest $N+1$ types assets, including a risk-free asset and $N$ types risky assets. The total investment income is obtained as follows:

$$
R=r p+g p\left(1-\sum_{i=1}^{N} \alpha_{i}\right) r_{0}+g p \sum_{i=1}^{N} \alpha_{i} r_{i}
$$

Where

$r$ : underwriting profitability, which is a random variable.

$r_{0}$ : The risk-free investment yield.

$r_{i}$ : The investment yields of investing $i^{\text {th }}$ type risky asset.

$g:$ The ratio of investment funds.

$\alpha_{0}$ : The proportion of investment risk-free asset.

$\alpha_{i}$ : The proportion of the $i^{\text {th }}$ risky asset investment, which is a controlled variable, and

$$
\alpha_{0}=1-\sum_{i=1}^{N} \alpha_{i}
$$

Therefore, the expected total profitability and total risk (variance) of insurance companies are respectively:

$$
\begin{aligned}
& E(R)=E(r)+g \alpha_{0} r_{0}+g \sum_{i=1}^{N} \alpha_{i} E\left(r_{i}\right) . \\
& \operatorname{Var}(R)=\operatorname{Var}(r)+2 g \sum_{i=1}^{N} \alpha_{i} \operatorname{Cov}\left(r, r_{i}\right)+\sum_{i, j=1}^{N} g^{2} \alpha_{i} \alpha_{j} \operatorname{Cov}\left(r_{i}, r_{j}\right) .
\end{aligned}
$$

Generally speaking, benefits and risks usually change in the same direction, because the profit is risk compensation. The companies weigh the total receipts and total risks with their appetite for risk, and maximize the benefits and minimize the risks to meet the needs of insurance payments among risk assets and risk-free assets portfolio. In order to take the benefits and risks into account, we establish a minimum risk portfolio strategy under certain profitability:

$$
\begin{aligned}
& \operatorname{Min}\left[\operatorname{Var}(R)=\operatorname{Var}(r)+2 g \sum_{i=1}^{N} \alpha_{i} \operatorname{Cov}\left(r, r_{i}\right)+\sum_{i, j=1}^{N} g^{2} \alpha_{i} \alpha_{j} \operatorname{Cov}\left(r_{i}, r_{j}\right)\right] . \\
& \text { s.t. } E(r)+g \alpha_{0} r_{0}+g \sum_{i=1}^{N} \alpha_{i} E\left(r_{i}\right)=E(R) . \\
& \alpha_{0}+\sum_{i=1}^{N} \alpha_{i}=1 \\
& \left(\alpha_{0}, \alpha_{i} \geq 0,(i=1,2, \cdots N)\right) .
\end{aligned}
$$

In the above model, the variance of profitability, risk level (variance) and the covariance between them are viewed as constants, while the weight of each asset is regarded to be a variable. The change of assets' weight will influence the expected profitability and risk, so we can adjust the weights to achieve optimal portfolio strategy.

\subsection{The calculation of efficient portfolio}

According to the portfolio model above, the values of the independent variables are as follows:

Constants:

$r_{0}$ : The risk-free investment yields, the average $r_{0}=2.28 \%$;

$g$ : The ratio of investment funds, the average $g=86.43 \%$;

Independent variables:

$r$ : underwriting profitability, and $E(r)=-3.47 \%$;

$r_{1}$ : The government bonds yield, and $E\left(r_{1}\right)=3.655 \%$; 
$r_{2}$ : The Corporate bonds yield, and $E\left(r_{2}\right)=3.845 \%$;

$r_{3}$ : The fund yield, and $E\left(r_{3}\right)=16 \%$

$r_{4}$ : The stock yield, and $E\left(r_{4}\right)=30.67 \%$;

Based on $\operatorname{Cov}\left(r_{i}, r_{j}\right)=E\left[\left(r_{i}-E\left(r_{i}\right)\right)\left(r_{j}-E\left(r_{j}\right)\right)\right]$, it can be calculated as follows:

Table 8 . The risk asset and underwriting yield variance-covariance

\begin{tabular}{cccccc}
\hline & $\begin{array}{c}\text { Government } \\
\text { bonds }\end{array}$ & $\begin{array}{c}\text { Corporate } \\
\text { bonds }\end{array}$ & Funds & Stock & $\begin{array}{c}\text { Underwriting } \\
\text { profitability }\end{array}$ \\
\hline Government bonds & $2.4133 * 10-5$ & $4.0134 * 10-5$ & $100.6105 * 10-5$ & $78.9413 * 10-5$ & $2.1885 * 10-5$ \\
\hline Corporate bonds & $4.0134 * 10-5$ & $8.9309 * 10-5$ & $215.9952 * 10-5$ & $143.326 * 10-5$ & $4.9348 * 10-5$ \\
\hline Funds & $100.615 * 10-5$ & $215.9952 * 10-5$ & $8335.9443 * 10-5$ & $8425.6278 * 10-5$ & $80.865 * 10-5$ \\
\hline $\begin{array}{c}\text { Stock } \\
\text { Underwriting } \\
\text { profitability }\end{array}$ & $78.9413 * 10-5$ & $143.326 * 10-5$ & $8425.6278 * 10-5$ & $11255.2733 * 10-5$ & $-1001.0033 * 10-5$ \\
\hline
\end{tabular}

Combining these data above and portfolio strategy model, we have:

$$
\begin{aligned}
& \operatorname{Min}\left[4.0243 * 10^{-5}+2 \times 0.8643 \sum_{i=1}^{4} \alpha_{i} \operatorname{Cov}\left(r, r_{i}\right)+\sum_{i, j=1}^{4} 0.8643^{2} \alpha_{i} \alpha_{j} \operatorname{Cov}\left(r_{i}, r_{j}\right)\right] . \\
& \text { S.t. }-3.47 \%+0.8643 \times 2.28 \% \alpha_{0}+0.8643 \times \sum_{i=1}^{4} \alpha_{i} E\left(r_{i}\right)=E(R) . \\
& \alpha_{0}+\sum_{i=1}^{N} \alpha_{i}=1 .
\end{aligned}
$$

Meanwhile, considering the regulations of CIRC for the investment ratio of assets, we can obtain $\alpha_{2} \times g \leq 50 \%$. And $g=86.43 \%$, so $\alpha_{2} \leq 57.85 \%$. In the same way, $\alpha_{3} \leq 28.93 \%$, $\alpha_{4} \leq 34.71 \%$.

According to solving method of the linear programming problem, it can be calculated as follows:

Table 9 The optimal portfolio of insurance funds

\begin{tabular}{ccccccccc}
\hline Profitability & 1 & 2 & 2.5 & 3 & 3.5 & 4 & 4.5 & 5 \\
\hline Variance & 2.537 & 9.271 & 15.17 & 21.34 & 25.91 & 32.93 & 38.9 & 45.93 \\
Bank & 0.698 & 0.693 & 0.537 & 0.399 & 0.3 & 0.11 & 0.125 & 0.092 \\
Government bonds & 0 & 0.063 & 0.172 & 0.289 & 0.39 & 0.413 & 0.432 & 0.446 \\
Corporate bonds & 0.178 & 0.201 & 0.211 & 0.228 & 0.228 & 0.224 & 0.217 & 0.223 \\
Funds & 0.011 & 0.003 & 0.038 & 0.049 & 0.061 & 0.131 & 0.122 & 0.153 \\
\hline Stock & 0.015 & 0.025 & 0.034 & 0.057 & 0.078 & 0.22 & 0.118 & 0.173 \\
\hline
\end{tabular}

\section{Conclusions}

\subsection{Innovation}

According to portfolio theory, the paper combines the theory and demonstration to analyze the optimal combination of insurance investment strategy.

This paper considers the insurance company stock investment income and uses the insurance portfolio theory model to get the optimal ratio of investment funds to invest, combined with the recent data of China's insurance investment income.

Through analysis the current investment ratio of the asset limit of the CIRC, the paper carries on further research and obtains the proportion of investment in the present and future of China's insurance funds, combined with the optimal investment ratio derived theoretical model. 


\subsection{Limitations}

Due to cognitive subjectivity, the limitations of ability and constraints on data collection, the limitations of the research does exist. China's current investment channels for insurance funds has been further widened, as can be invested in real estate investment and infrastructure investment plan debt and other new forms of investment. However, due to the current insurance companies invest only a small proportion of these investments, this paper didn't include.

\section{Suggestions}

Research on insurance portfolio develops with the development of China's insurance industry, and changes with the development of China's capital market and insurance investment products' increasing. This paper is just a stage conclusion, and I believe that the research on the insurance portfolio will enter a higher stage with the deepening of China's capital market reform and more well-written laws.

The process of development of China's insurance market funds business will not smooth. Completely open market does have a long way to go, and we also need to explore constantly. The following is some recommendations to promote the development of China's insurance portfolio:

Government should create a favorable environment for investment of insurance funds. First, it's urgent to improve the market mechanism and establish a scientific stock market development mechanism. Second, develop the corporate and financial bond market and enrich bond types. Finally, government should develop the stock index futures market. It's good for hedge against systemic risk of stock market if stock index futures can develop well.

Insurance companies should be fully aware of the current market environment and establish a sound risk management system. They should manage the asset dispersedly and diversely based on comprehensive asset and liability management so as to prevent the risk of spread loss that may result from the changes in interest rates.

Insurance companies need establish correct investment philosophy and select proper form of investment based on their own characteristics. They ought to optimize the structure of fixed-income products, reduce the proportion of bank deposits and increase the proportion of government bonds and corporate bonds, making full use of the domestic stock market, while controlling the domestic stock market investment risk.

Insurance companies must establish professional investment management mechanism. They would pay attention to develop and introduce high-quality professionals who have insurance or financial expertise in order to strengthen the insurance investment of qualified personnel. So the companies will have ability and integrity, high-quality, professional personnel and establish standardized, institutionalized and scientific insurance asset management system, then improve the professional level of insurance investment management.

\section{References}

[1] Information on http://www.iii.org/insurance_topics/.

[2] https://www.abi.org.uk/. Association of British Insurers website

[3] China Insurance Yearbook (2009-2014).

[4] http://www.sse.com.cn/. The Shanghai stock exchange website

[5] http://www.circ.gov.cn/web/site0/. China Insurance Regulatory Commission website

[6] Interim measures of management of insurance funds entrusted investment (2012).

[7] http://www.pbc.gov.cn/. People's Bank of China website - deposit interest rate table.

[8] Ping an Insurance Group Annual Report

[9] Feifei Liu. Markowitz portfolio model based on genetic algorithms. Ocean University of China. (2008)

[10] Linlin Guo. Discussion on China's investment funds under the new insurance regulations. Southwestern University of Finance and Economics. (June 2012) 